\title{
EFEKTIVITAS MODEL PEMBELAJARAN TAI DAN PBI TERHADAP HASIL BELAJAR MATEMATIKA SISWA KELAS VIII
}

\author{
Ernis Kristiana Dewi ${ }^{1}$, Putri Yulia ${ }^{* 2}$ \\ ${ }^{1}$ Universitas Riau Kepulauan, Batam, Kepulauan Riau, Indonesia \\ ${ }^{2}$ Institut Agama Islam Negeri (IAIN) Kerinci \\ e-mail: "putriyuliamz@gmail.com,
}

\begin{abstract}
Abstrak. Rendahnya hasil belajar siswa mungkin dipengaruhi oleh pemilihan dan penggunaan model konvensional yang kurang tepat. Tujuan dalam penelitian ini adalah untuk mengetahui keefektifanmodel Team Assisted Individualization (TAI) dan efektivitas model Problem Based Intruction (PBI) terhadap hasil belajar matematika siswa. Penelitian ini adalah penelitian eksperimen dengan desain penelitian Posttest Only Control Group Design. Populasi penelitian ini adalah seluruh siswa kelas VIII.Sampel diambil dengan teknik Cluster Random Sampling berjumlah 2 kelas, dengan rincian kelas VIII E untuk kelas eksperimen 1 dan kelas VIII F untuk kelas eksperimen 2. Instrumen penelitiannya tes hasil belajar matematika siswa berupa tes essay, yang telah diuji validitas, tingkat kesukaran, daya pembeda dan reliabilitas.Berdasarkan hasil penelitian bahwa: (1) Model pembelajaran TAI efektif terhadap hasil belajar siswa. (2) Model pembelajaran PBI efektif terhadap hasil belajar siswa. (3) Terdapat perbedaan keefektifan model pembelajaran TAI dan model pembelajaran PBI terhadap hasil belajar siswa dengan diperoleh nilai sig. (2-tailed) $=0,023<0,05$ maka $H_{0}$ ditolak dan $\mathrm{H}_{\mathrm{a}}$ diterima maka, dapat disimpulkan bahwaterdapat perbedaan hasil belajar matematika siswa dengan menggunakan model pembelajaran TAI dan PBI.
\end{abstract}

Kata kunci:TAI, PBI dan Hasil Belajar.

Abstract. Students' low learning outcomes can be affected by incorrect selection and use of learning model. This research aims to find out the effectiveness of Team Assisted Individualization (TAI) and Problem Based Instruction (PBI) Learning Model toward students' mathematics learning outcomes. It was an experimental research with Posttest Only Control Design. The population of this research was all eighth grade students. Sampling was done with Cluster Random Sampling consisted of 2 class, in which VIII E class was for experiment class 1 and VIII F was for experimental class 2 . The instrument of the research was students' mathematic learning outcome test which had been tested for its validity, level of difficulty, differentiating level, and reliability. The result of the research shows that: (1) TAI Learning Model is effective toward learning outcomes, (2) PBI Learning Model is effective toward learning outcomes, (3) There are differences between TAI and PBI Learning Model toward learning outcomes where score of sig. 2 tailed $=0,023<0.05$, meaning $\mathrm{Ho}$ is rejected and accepted, so it can be concluded that there are differences in students' mathematics learning outcomes between the use of TAI and PBI Learning Model.

Key Words: TAI, PBI and Learning Outcomes

\section{Pendahuluan}

Pembelajaran matematika merupakan upaya untuk menciptakan suatu kondisi siswa untuk belajar. Adanya proses interaksi siswa dengan guru dan sumber belajar pada suatu lingkungan belajar, di dalam pembelajaran yang efektif. Pembelajaran dikaitkan dengan mata pelajaran yang akan dibahas, dalam hal ini adalah matematika. Pembelajaran matematika adalah suatu kegiatan yang dirancang antara guru dan siswa, dimana guru mata pelajaran matematika merupakan pusat dari proses pembelajaran serta melibatkan partisipasi aktif dari siswa yang berada di dalamnya sehingga tujuan dari kegiatan tersebut untuk menciptakan suasana lingkungan memungkinkan seseorang melaksanakan kegiatan belajar matematika 
dapat terwujud (Hamzah \& Muhlisrarini, 2014).

Matematika adalah ilmu abstrak yang perlu dipelajari setiap individu, karena matematika sangat berperan penting dalam perkembangan ilmu dan teknologi. Mempelajari matematika, secara tidak langsung akan merubah cara berfikir setiap individu. Begitu pentingnya ilmu matematika dalam kehidupan kita, maka sangat penting bagi kita untuk menguasai ilmu matematika itu sendiri. Matematika juga melatih siswa untuk mengembangkan kemampuan dalam menarik kesimpulan, kreatif, mampu menyelesaikan masalah, dan pembentukan ketampilan matematika untuk mengubah tingkah laku siswa. Perubahan tingkah laku siswa akan terlihat pada akhir proses pembelajaran yang mengacu pada hasil belajar (Ratnasari \& Yulia, 2018).

Berdasarkan hasil observasi yang telah peneliti lakukan di SMP Negeri 50 Batam pada kelas VIII, pada saat Program Pengalaman Lapangan (PPL) yang berlangsung dari bulan Agustus sampai dengan bulan Desember 2016, menunjukkan bahwa siswa tersebut masih menganggap matematika itu menakutkan untuk dipelajari, mereka masih mengeluh kesusahan untuk memecahkan masalah dalam pelajaran matematika, kurangnya kepercayaan diri siswa untuk tidak mengajukan pertanyaan apabila ada yang belum dipahami serta kurangnya kepercayaan diri dalam menjawab pertanyaan yang diberikan oleh guru, siswa yang tidak mengerti dan tidak memahami hanya duduk diam sampai jam pelajaran habis. Hal ini disebabkan keaktifan siswa tersebut sangat kurang ketika pembelajaran berlangsung. Selain itu, masih banyak siswa yang merasa kesulitan dalam menyelesaikan soal yang berkaitan dengan materi yang diajarkan, kemungkinan karena konsep-konsep tentang materi yang dipelajari tersebut belum benar-benar dikuasai oleh siswa. Oleh sebab itu siswa cenderung pasif dan hanya mendengarkan penjelasan dari guru. Proses pembelajaran yang berlangsung masih mengandalkan guru sebagai pemberi seluruh informasi sehingga membuat minat belajar siswa rendah, seperti orang yang kalah sebelum bertanding. Hal ini dapat dilihat pada tabel 1 yang menunjukkan nilai mid semester matematika siswa yang masih rendah dilihat dari persentase nilai siswa yang masih dibawah KKM yaitu 72 .

Tabel 1. Persentase Ketercapaian KKM NilaiMid Semester Siswa Kelas VIII SMP N 50 Batam Tahun Pelajaran 2016/2017

\begin{tabular}{cccccccc}
\hline NO & Kelas & $\begin{array}{c}\text { Jumlah } \\
\text { Siswa }\end{array}$ & KKM & Tuntas & $\begin{array}{c}\text { Jumlah } \\
\text { Siswa }\end{array}$ & $\begin{array}{c}\text { Tidak } \\
\text { Tuntas }\end{array}$ & $\begin{array}{c}\text { Jumlah } \\
\text { Siswa }\end{array}$ \\
\hline 1 & VIII.A & 40 Siswa & 72 & $57,5 \%$ & 23 & $42,5 \%$ & 17 \\
2 & VIII.B & 40 Siswa & 72 & $45 \%$ & 18 & $55 \%$ & 22 \\
3 & VIII.C & 40 Siswa & 72 & $52,5 \%$ & 21 & $47,5 \%$ & 19 \\
4 & VIII.D & 39 Siswa & 72 & $46,2 \%$ & 18 & $53,8 \%$ & 21 \\
5 & VIII.E & 39 Siswa & 72 & $30,7 \%$ & 12 & $69,3 \%$ & 27 \\
6 & VIII.F & 39 Siswa & 72 & $28,2 \%$ & 11 & $71,8 \%$ & 28 \\
\hline
\end{tabular}

Sumber : Guru Mata Pelajaran Matematika kelas VIII SMP N 50 Batam

Salah satu alternatif model pembelajaran yang dirasa dapat digunakan dalam meningkatkan keaktifan siswa dalam memecahkan masalah dalam soal matematika adalah model pembelajaran Team Assisted Individualization (TAI) dan Problem Based Intruction (PBI). TAI merupakan salah satu model pembelajaran kooperatif yang mengkombinasikan 
keunggulan pembelajaran kooperatif dan pembelajaran individual (Lestari \& Yudhanegara, 2017). Sejalan dengan pendapat Daulay\& Simarmata (Daulay, N. H., \& Simarmata, 2014) model pembelajaran TAI dipilih karena siswa termotivasi dan aktif untuk saling membantu dan mempersiapkan diri menguasai pelajaran yang diberikan. Ini terlihat pada saat para siswa belajar dalam kelompok, para siswa saling membantu dan berdiskusi dalam mengerjakan dan memecahkan persoalan yang ada pada LKS dan menjawab pertanyaan yangdiajukan oleh guru. Siswa juga mampu berpikir logis dankritis, teliti dalam mengerjakan soal dan disiplin. Model pembelajaran TAI berdampak positif dalam meningkatkan hasil belajar siswa, sebab dalam pembelajaran ini siswa bekerja sama dalam kelompok untuk menyelesaikan tugas yang diberikan oleh guru sehingga mereka lebih berani untuk aktif bertanya kepada kelompoknya apa saja yang belum mereka pahami. Karena dengan temannya sendiri tidak ada rasa enggan, rendah diri, canggung, dan takut sehingga para siswa akan lebih termotivasi untuk mempelajari materi-materi yang diberikan oleh guru (Ratnasari \& Yulia, 2018).

PBI merupakan model pembelajaran yang menggunakan masalah dunia nyata sebagai suatu konteks untuk belajar tentang cara berpikir kritis dan keterampilan pemecahan masalah, serta memperoleh pengetahuan dan konsep yang essensial dari mata pelajaran (Purwaningsih, Amirudin, \& Suharto, 2012), Hal yang terpenting adalah siswa akan diberi kesempatan untuk mengembangkan kemampuan pemecahan masalahdan daya temu melalui masalah-masalah yang sengaja disajikan oleh gurumaupun muncul sendiri dari siswa. Sedangkan menurut penelitian Titin (Sari, 2013) menyatakan bahwa dengan penggunaan model pembelajaran PBI dapat meningkatkan hasil belajar siswa dan meningkat pula pemahaman terhadap materi karena siswa dituntut aktif untuk belajar memahami dengan penyelidikan sendiri sehingga siswa mampu menerapkannya dalam kehidupan sehari-hari. Berdasarkan hasil penelitian ini, maka guru perlu memperhatikan kemampuan siswa dengan diterapkannya model pembelajaran agar hasil belajar siswa dapat meningkat. Berdasarkan latar belakang di atas, maka peneliti tertarik untuk melakukan penelitian dengan judul "Efektivitas Model Pembelajaran TAI dan PBI terhadap Hasil Belajar Matematika Siswa Kelas VIII”.

\section{Metode Penelitian}

Jenis penelitian yang digunakan dalam penelitian ini adalah penelitian kuantitatif. Metode penelitian ini menggunakan penelitian kuasi eksperimen. Desain penelitian yang digunakan dalam penelitian ini adalah Posttest Only Control Design.

Populasi dalam penelitian ini adalah seluruh siswa kelas VIII SMPN 50 Batam Tahun Ajaran 2016/2017 yang terdiri dari kelas VIII A, VIII B, VIII C, VIII D, VIII E, VIII F dengan jumlah siswa sebanyak 237 orang siswa.Pengambilan sampel pada penelitian ini adalah dengan teknik Cluster Random Sampling. Kemudian peneliti melakukan pemilihan kelas secara acak dengan catatan apabila terpilih kelas VIII A maka pemilihan diulangi karena kelas tersebut memiliki rata-rata nilai kelas yang jauh lebih tinggi dibandingkan dengan ke-5 kelas lainnya.Sehingga peneliti mendapatkan dua kelas eksperimen yaitu kelas VIII E dan kelas VIII F. Penelitian telah dilaksanakan pada bulan Maret 2017 sampai dengan April 2017. 
Variabel bebas dalam penelitian ini adalah TAI $\left(\mathrm{X}_{1}\right)$ dan PBI $\left(\mathrm{X}_{2}\right)$.Variabel terikat dalam penelitian ini adalah hasil belajar matematika siswa (Y) kelas VIII SMPN 50 Batam.Teknik pengumpulan data yang digunakan dalam penelitian ini adalah menggunakan tes.Tes digunakan untuk mengetahui hasil belajar siswa setelah melaksanakan pembelajaran berupa soal uraian sebanyak 4 soal untuk post-test. Peneliti menggunakan validitas konstruk dengan dengan rumus Product Moment. Kemudian Tingkat kesukaran pada instrumen memiliki kriteria yang mudah dan sedang dan Daya Pembeda pada instrumenmemiliki kriteria yang baik dan cukup. Sedangkan untuk menguji reliabilitas instrumen tes dalam penelitan ini, digunakan rumus alfa Crombach karena jenis data yang digunakan berbentuk internal atau essay.Hasil dari koefisien alfa Crombach pada instrumen post-test yaitu 0,869 sehingga memiliki kriteria reliabilitas yang tinggi. Sedangkan untuk uji prasyarat dalam penelitian ini adalah normalitas menggunakan uji kolmogorov smirnov, dan uji homogenitas menggunakan uji levene statistic. Untuk analisis uji hipotesis menggunakan uji t satu sampel (one sampel ttest), dan uji t dua sampel (independent sample t-test).

\section{Hasil Penelitian Dan Pembahasan}

Setelah dilakukan perlakuan pembelajaran pada kelas eksperimen 1 dengan model pembelajaran TAI dan pada kelas eksperimen 2 dengan model pembelajaran PBI diperoleh data hasil hasil post-test pada tabel 2.

Tabel 2. Ringkasan hasil postes siswa

\begin{tabular}{lllllllll}
\hline & $\mathrm{n}$ & Range & Min & Skor ideal & Max & Mean & S.Deviasi & Varians \\
\hline TAI & 39 & 40 & 60 & 100 & 100 & 82,31 & 11,462 & 131,377 \\
PBI & 39 & 40 & 55 & 100 & 95 & 76,28 & 11,455 & 131,208 \\
\hline
\end{tabular}

Berdasarkan tabel 2 hasil olah data statistik di atas menunjukkan bahwa rata-rata skor post-test kelas ekperimen I yang mendapat perlakuan model pembelajaran TAI yakni kelas VIII.E lebih tinggi daripada kelas eksperimen II yang mendapat perlakuan model pembelajaran PBI yakni kelas VIII.F.

Sebelum data dianalisis untuk menguji hipotesis, terlebih dahulu data harus memenuhi syarat normal dan homogen. Data diperoleh dari hasil post-test yang diberikan setelah perlakuan pada kelompok sampel yang telah dilaksanakan. Pada uji prasyarat ini, uji normalitas menggunakan uji Kolmogrov-Smirnov, sedangkan uji homogenitas menggunakan uji Levene Statistic dengan bantuan SPSS for windows version 20.0.

Setelah dilaksanakan penelitian atau perlakuan terhadap kelas eksperimen 1, sampel diberikan soal post-test untuk mengetahui sejauh mana perkembangan kemampuan siswa. Setelah mendapat data hasil post-test tersebut maka dilakukan uji normalitas. Berdasarkan data yang diperoleh, nilai signifikansi kelas eksperimen 1 adalah 0,200 dan kelas eksperimen 2 adalah 0,200 maka dapat disimpulkan bahwa (Sig) $\geq 0.05$, maka data kelas eksperimen 1 dan kelas eksperimen 2 berdistribusi normal. Sedangkan Uji homogenitas dilakukan dengan membandingkan nilai variansi data nilai post-test dari kelas eksperimen 1 dan kelas eksperimen 2. Hasil uji homogenitas yang diperoleh peneliti, nilai signifikasi 0,942 dan 0,942 lebih besar dari $0,05(\alpha)$ sehingga dapat disimpulkan bahwa data penelitian di atas artinya variannya sama/homogen. 
Kelas ekeperimen 1 pada penelitian ini adalah kelas VIII E SMPN 50 Batam dengan menggunakan model pembelajaran TAI. Hipotesis kelas eksperimen 1 diuji dengan menggunakan uji statistik one sample t-test yang dalam pengerjaannya, peneliti menggunakan bantuan SPSS for windows version 20.0. Berdasarkan hasil pengujian one sample $t$ testdiperoleh nilai signifikansinya adalah $0,000 / 2=0,000$. Karena $0,000<0,025$ maka artinya model pembelajaran kooperatif TAI efektif terhadap hasil belajar matematika siswa kelas VIII SMP Negeri 50 Batam Tahun Pelajaran 2016/2017.

Pembelajaran dengan menggunakan model TAI ini sangat berpengaruh bagi siswa, karena model pembelajaran ini menuntut siswa untuk belajar aktif didalam kelas yaitu belajar individual yang memahami materi yang diberikan oleh peneliti, diskusi kelompok dan mempresentasikan jawaban. Masing-masing kelompok saling membantu teman yang tidak memahami materi, sehingga siswa lebih mudah mempelajari dan memahami materi tersebut hal ini sejalan dengan pendapat Indriyani (Indriani, 2016) yang mengatakan bahwa model pembelajaran TAI dipilih karena berdampak positif dalam meningkatkan hasil belajar siswa, sebab dalam pembelajaran ini siswa bekerja sama dalam kelompok untuk menyelesaikan tugas yang diberikan oleh guru sehingga mereka lebih berani untuk aktif bertanya kepada kelompoknya apa saja yang belum mereka pahami. Karena dengan temannya sendiri tidak ada rasa enggan, rendah diri, canggung, dan takut sehingga para siswa akan lebih termotivasi untuk mempelajari materi-materi yang diberikan oleh guru. Menurut Hariyati (Lestari \& Yudhanegara, 2017) mengemukakan bahwa model pembelajaran kooperatif tipe TAI tersebut dapat meningkatkan hasil belajar siswa, model pembelajaran TAI yang membentuk kelompok kecil yang heterogen dengan latar belakang cara berfikir yang berbeda untuk saling membantu terhadap siswa lain yang membutuhkan bantuan. Dalam hal ini diterapkan bimbingan antar teman yaitu siswa yang pandai bertanggung jawab terhadap siswa yang kurang pandai, disamping itu dapat meningkatkan partisipasi siswa dalam kelompok kecil. Siswa yang pandai dapat mengembangkan kemampuan sedangkan siswa yang kurang pandai dapat menyelesaikan permasalahannya.

Kelas ekeperimen 2 pada penelitian ini adalah kelas VIII F SMPN 50 Batam dengan menggunakan model pembelajaran PBI. Hipotesis kelas eksperimen 2 diuji dengan menggunakan uji statistik one sample t-test yang dalam pengerjaannya, peneliti menggunakan bantuan SPSS for windows version 20.0. Berdasarkan hasil pengujian one sample t-test diperoleh nilai signifikansinya adalah $0,025 / 2=0,0125$. Karena $0,0125<0,025$ maka artinya model pembelajaran kooperatif PBI efektif terhadap hasil belajar matematika siswa kelas VIII SMP Negeri 50 Batam Tahun Pelajaran 2016/2017.

Penerapan model pembelajaran PBI, tingkat aktivitas siswa semakin meningkat karena siswa benar-benar mengerti dengan apa yang dipelajarinya sehingga rasa ingin tahu yang ada dalam diri mereka semakin tinggi dan akhirnya proses kerja sama yang baik akan terjadi, semua siswa bekerja dan saling bertukar pikiran hal ini senada dengan Rahmawati dan Purnamasari menyatakan bahwa siswa yang belajar dengan menggunakan model pembelajaran Problem Based Instruction (PBI) memiliki hasil belajar yang lebih baik, karena model pembelajaran Problem Based Instruction dapat secara aktif belajar secara mandiri, 
siswa dilibatkan pada kegiatan belajar sehingga pengetahuannya benar-benar diserapnya dengan baik, siswa dilatih untuk bekerja sama dengan siswa lain, siswa dapat memperoleh pengetahuan dari berbagai sumber untuk memecahkan masalah dan mengeluarkan ide sehingga pemahaman dan hasil belajar siswa menjadi lebih baik (Rahmawati \& purnamasari, 2016). Hal ini juga sejalan dengan pendapat penelitian Titin (Sari, 2013) menyatakan bahwa dengan penggunaan model pembelajaran PBI dapat meningkatkan hasil belajar siswa dan meningkat pula pemahaman terhadap materi karena siswa dituntut aktif untuk belajar memahami dengan penyelidikan sendiri sehingga siswa mampu menerapkannya dalam kehidupan sehari-hari.

Hipotesis ketiga pada penelitian ini bertujuan untuk mengetahui apakah terdapat perbedaan antara model pembelajaran TAI dan PBI terhadap hasil belajar matematika siswa SMPN 50 Batam.Pengujian hipotesis ketiga yaitu menggunakan independent sample t-test. Untuk perhitungan uji hipotesis 3 menggunakan bantuan SPSS for windows 20. Berdasarkan hasil olah, diperoleh nilai sig. (2-tailed) $=0,023<0,05$ maka dapat disimpulkan bahwaterdapat perbedaan hasil belajar matematika siswa kelas VIII SMP Negeri 50 Batam Tahun Pelajaran 2016/2017 dengan menggunakan model pembelajaran TAI dan PBI.

Dalam pembelajaran antara dua model tersebut terlihat perbedaan antara model pembelajaran TAI dan PBI, perbedaan yang terlihat antara kedua model tersebut adalah model pembelajaran TAI lebih efektif dibandingkan dengan model pembelajaran PBI. Hal tersebut dikarenakan pada model pembelajaran PBI siswa belum bisa menemukan konsep baru berdasarkan permasalahan yang diberikan, mereka masih memerlukan bantuan atau dorongan untuk menyelesaikan permasalahan matematika. Pada presentasi kedepan kelas hasilnya pun beberapa siswa terlihat malu-malu hal ini dikarenakan waktu yang singkat dan masih kurangnya pemahaman siswa untuk memecahkan suatu permasalahan. Sedangkan model pembelajaran TAI ini lebih menekankan kepada bagaimana siswa menyelesaikan dan menemukan sebuah konsep. Sedangkan pada penerapan model pembelajaran TAI, model ini menekankan kerja sama dan tanggung jawab atas tugas individu dan kelompok. Pada penerapan model ini terlihat siswa lebih aktif, mandiri serta percaya diri saat mempresentasikan materi di depan kelas. Hal ini dikarenakan apa yang akan mereka presentasikan di depan kelas sudah mereka diskusikan bersama.

\section{Kesimpulan Dan Saran}

Berdasarkan rumusan masalah yang diajukan dan hasil penelitian yang didapat, maka dapat ditarik kesimpulan:

a. Model pembelajaran kooperatif TAI efektif terhadap hasil belajar matematika siswa kelas VIII SMP Negeri 50 Batam Tahun Pelajaran 2016/2017.

b. Model pembelajaran kooperatif PBI efektif terhadap hasil belajar matematika siswa kelas VIII SMP Negeri 50 Batam Tahun Pelajaran 2016/2017.

c. Terdapat perbedaan keefektifan hasil belajar matematika kelas VIII SMPNegeri 50 Batam Tahun Pelajaran 2016/2017 dengan menggunakan model pembelajaran kooperatif TAI dan PBI.

Saran yang dapat disampaikan peneliti adalah diharapkan para stakeholder untuk dapat lebih memperhatikan bahwa salah satu model pembelajaran yang efektif untuk meningkatkan 
hasil belajar matematika siswa adalah dengan menerapkan model pembelajaran Team Assisted Individualization (TAI) dan Problem Based Intruction (PBI).

\section{DAFTAR PUSTAKA}

Daulay, N. H., \& Simarmata, U. (2014). Perbedaan Hasil Belajar Siswa Dengan Menggunakan Model Pembelajaran Kooperatif Tipe Team Assisted Individualization (TAI) Dan Model Konvensional Pada Materi Pokok Tekanan Kelas VIII SMP Negeri 5 STABAT TP 2013/2014. INPAFI (Inovasi Pembelajaran Fisika), 2(4).

Hamzah, A., \& Muhlisrarini. (2014). Perencanaan \& Strategi Pembelajaran Matematika. Jakarta: Rajawali Press.

Indriani, R. (2016). Pengaruh Model Team Assisted Individualization Terhadap Hasil Belajar IPS Kelas V SD Negeri Jurugentong. Jurnal Kurikulum Dan Tekhnologi Pendidikan.

Lestari, K. E., \& Yudhanegara, M. (2017). Penelitian Pendidikan Matematika. Bandung: Refika Aditama.

Purwaningsih, I., Amirudin, A., \& Suharto, Y. (2012). Model Pembelajaran Problem Based Instruction (PBI) Untuk meningkatkan keaktifan belajar dan Berpikir Kritis Siswa. Uharto Jurnal, 5(2). Retrieved from http://jurnalonline.um.ac.id/data/artikel/artikelE67FDF9F7E69BEB865ABE1DC9CD3E489.pdf

Rahmawati, \& purnamasari. (2016). Penerapan Model Problem Based Instruction (PBI) dipandu media audio visual terhadap hasil belajar siswa pada materi kulit di kelas XI Mia SMA Negeri 3 Biuren. Variasi, 08(01), 23-32.

Ratnasari, D., \& Yulia, P. (2018). Efektivitas Model Pembelajaran Problem Based Learning (PBL) dan Team Assisted Individualization (TAI) Terhadap Kemampuan Pemecahan Masalah Matematis. PYTHAGORAS: Jurnal Pendidikan Matematika, 7(1), 1-8.

Sari, A. P. A. (2013). Penerapan Metode Pembelajaran Problem Based Intruction (PBI) Untuk Meningkatkan Kemandirian Belajar Matematika Pada Kelas IV SDN Simo Kabupaten Ngawi. Universitas Muhammadiyah Surakarta. Retrieved from http://eprints.ums.ac.id/27592/ 